\title{
Dental Radiographics Aspects in Gaucher Disease
}

\author{
Elza Maria Carneiro Mendes Ferreira dos Santos ${ }^{1 *}$, Vanessa de Araújo Faria ${ }^{2}$ and Plauto Christopher Aranha \\ Watanabe $^{3}$ \\ ${ }^{1}$ Dentist-Radiologist-Postgraduating in Images Sciences and Medical Physics of the Medical School of Ribeirão Preto University of São Paulo, Brazil \\ ${ }^{2}$ Dentist-Radiologist-Postgraduating in Bucal Diagnosis of Dental of University of São Paulo, Brazil \\ ${ }^{3}$ Professor of Medical Clinics of the Ribeirão Preto Medicine School and Full Professor at the Ribeirão Preto Dental School of University of São Paulo, \\ Brazil
}

Submission: October 26, 2017; Published: November 10, 2017

*Corresponding author: Elza Maria Carneiro Mendes Ferreira dos SANTOS, Street: Joaquim Mourão, 353 - 2º andar- sala 02- Centro Leme SP. Cep 13.610-070, Brazil, Fax: (19)35733300; (19)992304452; Email: santoselzacarneiro@gmail.com

\section{Abstract}

The knowledge about Gaucher disease, the main characteristics, clinical alterations and radiographic aspects described in this review, demonstrate that the clinical investigation should be used for anamnesis, laboratory tests and radiological images among them the dental ones, making possible the early detection in the manifestations mouth disease and success in disease control and treatment.

Keywords: Gaucher disease; Neuronopathic Gaucher Disease; Gaucher Disease Type1

\section{Introduction}

Gaucher disease (GD) was first described in 1882. It is a systemic lysosomal storage disorder caused by hereditary deficiency - an autosomal recessive disorder resulting from pathogenic mutations in the gene thatencodes glucocerebrosidase enzyme, resulting in an accumulation of glucocerebrosides in the phagocytes and central nervous system (CNS). The cell has the appearance of "Signature Rings with Crumpled Kleenex". The lipid stored in the lysosomes overflows into the cytoplasm, and the glycosylceramide is converted into glycosylsphingosine, with an increase in its serum levels. The production of these bioactive lipids involves other types of cells, such as the immune system, which secretes cytokines that are responsible for bone destruction and participation in the onset and spread of the pathogenesis of the disease. Pathophysiologically, Gaucher cells are characterized by distended phagocytic cells found in spleen, liver, and bone marrow, among others, Beutler et al. [1].

In the general population, the estimated frequency is in the range of $1: 50,000$ to $1: 100,000$ [2]. Found mostly in the Ashkenazi Jewish population, with a rate of 1:17 and an expected 1:850 birth rate Beutler et al[1] (1993). Two distinct forms of the disease are also relatively more common in the northern Norrbotten region of Sweden [3] and near the Palestinian city of Jenin [4]. Among the Ashkenazi Jews, the N370S mutations, which are associated with the milder expression of the disease [5], is more common. This article intends to address the importance of knowledge of Gaucher disease to the dentist, considering the initial radiographic evaluation.

\section{Manifestations In The Jaws}

There are case reports of patients with some degree of mandibular-maxillofacial involvement, frequently observed accidentally on routine dental or panoramic radiographs [6]. The most common radiographic observation is the presence of pseudocystic radiolucent lesions or honeycomb, well-defined lesions, especially in the premolar regions, [7]. The increase in osteopenia and the generalized rarefaction of trabecular bone are commonly observed. Other radiographic findings include osteoporosis, enlargement of bone marrow spaces, and in some cases apical root resorption, all presumably due to Gaucher cell density, $[8,9]$.

Areas of mandibular radiopacity were presented as being due to temporary bone regeneration after extraction, Bender I. B. [9] or to a sclerotic reaction to the infiltration of Gaucher cells. The involvement of the jaws is similar to skeletal extragnathic involvement, which accounts for $90 \%$ of patients, all cases involving the jaw, while only one quarter affects the maxilla. According to some authors, this is due to the fact that the mandible is considered a long bone. It is important to note that even this picture may be relatively benign and spontaneously reversed, because these "lesions" are Gaucher cells that act as "petrified" Gaucher bones. 


\section{Open Access Journal of Surgery}

This loss of normal trabecularization is observed in other long bones in Gaucher disease. Both the arches, maxilla and jaw can be affected by these phenomena. Apparently, the loss of corticalization of the mandibular canal, thinning of the cortical and hard lamina, obliteration of the maxillary sinus can be attributed to this process, observing other phenomena caused by the massive infiltration of Gaucher cells, which radiographically appear well-defined cells, circumscribed radiolucent lesions, similar to other cysts and tumors in the mandible. This lesion may present a soap bubble aspect (10.8\%), dislocate mandibular canal or teeth and root resorption [10-16].

\section{Materials and Methods}

Articles and protocols [16] were reviewed as clinical and radiographic citations [13] (Table 1) of relevance to the quality of dental treatment.

\section{Result and Discussion}

The gold standard for the diagnosis of Gaucher disease is the detection of low levels of enzyme activity in peripheral blood cells compared to normal control samples taken on the same day. Molecular analyzes of the genotype sometimes serve as an adjuvant in assessing the potential trajectory of disease severity Zimran [5] (2011). For dentistry, the possibility of assisting in the early recognition of Gaucher Disease would be very interesting because of the radiographic characteristics, which are in fact confused with several other situations, such as, for example, mandibular osteoporosis, except type 2, which affects mainly children, or other bone diseases, such as ameloblastoma.

Sclerosis or erosion of the cortex occur on the endosteal surface. This finding is not specific for Gaucher disease, and it can be found in hemolytic anemias, leukemia, hyperthyroidism, former consolidated fractures, and Albers-Schonberg disease. Involvement of the jaw, skull, hands and feet is rare, Mendonça et al. [15]. As shown in (Table 1), there are several manifestations of dental interest, which will interfere directly in the planning of the case, since many of these children / adolescents / adults are receiving dental treatment without knowledge of the disease, as well as in treatments, without the dentist knowing these manifestations $[17,18]$.

Table 1: Demographic and radiological characteristics of patients with Gaucher disease involving the mandible, reported in the literature between 1982 e 2012 [10].

\begin{tabular}{|c|c|c|c|}
\hline \multicolumn{2}{|c|}{ Demographic Feature } & $\mathbf{N}$ & $\%$ \\
\hline \multirow{2}{*}{\multicolumn{2}{|c|}{ Gênero }} & $16(\mathrm{M})$ & 43 \\
\hline & & $21(\mathrm{~F})$ & 57 \\
\hline \multicolumn{2}{|c|}{ Age at first presentation in maxillaries (years) } & $33,8+-13,6$ & \\
\hline \multicolumn{2}{|c|}{ Enzyme Replacement Therapy } & 18 & 48,6 \\
\hline \multirow{5}{*}{ Available radiographs } & Periapical & 5 & 13,5 \\
\hline & Lateral & 3 & 8 \\
\hline & Panoramic & 33 & 89,2 \\
\hline & Computed tomography & 5 & 13,5 \\
\hline & Magnetic Resonance Imaging & 1 & 2,7 \\
\hline \multicolumn{4}{|c|}{ Radiographic characteristics } \\
\hline \multirow{2}{*}{ Location } & Lower Jaw & 36 & 97,3 \\
\hline & Upper Jaw & 9 & 24,3 \\
\hline \multirow{4}{*}{ Periphery } & Well defined & 15 & 40,5 \\
\hline & Cortical Edge & 13 & 35,1 \\
\hline & Curved Edge & 14 & 37,8 \\
\hline & Invagination & 11 & 29,7 \\
\hline \multirow{5}{*}{ Internal structure } & $\begin{array}{c}\text { Rarefaction of trabeculate, } \\
\text { Osteopenia }\end{array}$ & 31 & 83,8 \\
\hline & $\begin{array}{l}\text { Enlargement of the medullary } \\
\text { spaces }\end{array}$ & 27 & 73 \\
\hline & Fully radiolucent & 15 & 40,5 \\
\hline & Soap Bubble Standard & 4 & 10,8 \\
\hline & Radiopaque areas & 5 & 13,5 \\
\hline \multirow{4}{*}{ Effects on Adjacent Structures } & Tooth displacement & 4 & 10,8 \\
\hline & Root reabsorption & 9 & 24,3 \\
\hline & Late teeth eruption & 5 & 13,5 \\
\hline & Hard blade thinning & 5 & 13,5 \\
\hline
\end{tabular}




\section{Open Access Journal of Surgery}

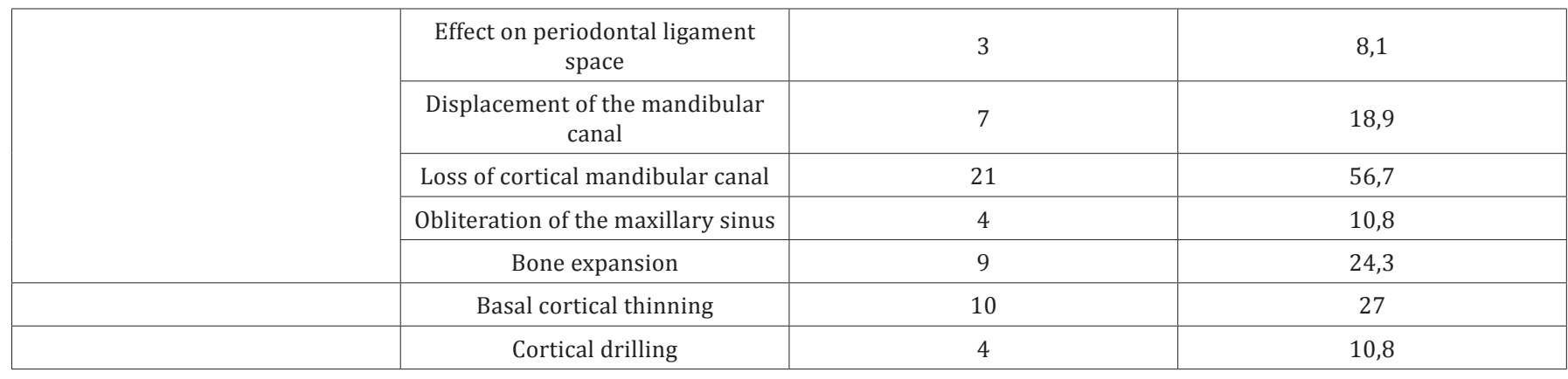

\section{Conclusion}

The importance of clinical and family history with detailed anamnesis is of vital importance in the evaluation of patients with lysosomal storage disorders. Dental radiographic examinations help in the identification of changes, in the planning and treatment plan.

\section{References}

1. E Beutler, NJ Nguyen, MW Henneberger, JM Smolec, RA Mcpherson, et al. (1993) Gaucher disease: gene frequencies in the Ashkenazi Jewish population. American journal of human genetics 52(1): 85.

2. Peter J Meikle, John J Hopwood, Alan E Clague (1999) Prevalence of lysosomal storage disorders. Jama 281(3): 249-254.

3. Svennerholm L (1991) Norrbottnian type of Gaucher disease-clinical, biochemical and molecular biology aspects: successful treatment with bone marrow transplantation. Developmental neuroscience 13(4-5): 345-351.

4. Abrahamov A, Elstein D, Zimran A, Farber B, Glaser Y, et al. (1995) Gaucher's disease variant characterised by progressive calcification of heart valves and unique genotype. The Lancet 346(1981): 1000-1003.

5. Zimran A (2011) How I treat Gaucher disease. Blood 118(6): 14631471.

6. Hallak CEM (1997) Coagulation abnormalities in type 1 Gaucher disease are due to low-grade activation and can be partly restored by enzyme supplementation therapy. British journal of haematology 96(3): 470476

7. Bender IB (1938) Dental observations in Gaucher's disease. Journal of Dental Research 17(5): 359-369.

8. Carter LC (1998) The nature and extent of jaw involvement in Gaucher disease: observations in a series of 28 patients. Oral Surgery, Oral
Medicine, Oral Pathology, Oral Radiology, and Endodontology 85(2): 233-239.

9. Bender IB (1959) Dental observations in Gaucher's disease: A twentyyear follow-up. Oral Surgery, Oral Medicine, Oral Pathology 12(5): 546561.

10. Zeevi I (2013) Jaws features in Type 1 Gaucher disease. Journal of Oral and Maxillofacial Surgery 71(4): 694-701.

11. Wenstrup RJ (2002) Skeletal aspects of Gaucher disease: a review. The British journal of radiology 75(suppl 1): A2-A12.

12. Bildman, B, Martinez JR, M Robinson LH (1972) Gaucher's disease discovered by mandibular biosy: report of case. Journal of oral surgery (American Dental Association: 1965) 30(7): 510.

13. Lustmann J (1991) Gaucher's disease affecting the mandible and maxilla: Report of a case. International journal of oral and maxillofacial surgery 20(1): 7-8.

14. Clínico, Protocolo, and Diretrizes Terapêuticas. Doença DE gaucher. Protocolos clínicos E diretrizes terapêuticas: 159.

15. Mendonça VF (2001) Manifestações esqueléticas da doença de gaucher. Radiologia Brasileira 34(3): 151-154.

16. Barton NW (1991) Replacement therapy for inherited enzyme deficiency- macrophage-targeted glucocerebrosidase for Gaucher's disease. New England Journal of Medicine 324(21): 1464-1470.

17. Zimran A (1995) Replacement therapy with imiglucerase for type 1 Gaucher's disease. The Lancet 345(8963): 1479.

18. Weinreb NJ (2002) Effectiveness of enzyme replacement therapy in 1028 patients with type 1 Gaucher disease after 2 to 5 years of treatment: a report from the Gaucher Registry. The American journal of medicine 113(2): 112-119.

\section{Your next submission with Juniper Publishers} will reach you the below assets

- Quality Editorial service

- Swift Peer Review

- Reprints availability

- E-prints Service

- Manuscript Podcast for convenient understanding

- Global attainment for your research

- Manuscript accessibility in different formats

( Pdf, E-pub, Full Text, Audio)

- Unceasing customer service

Track the below URL for one-step submission https://juniperpublishers.com/online-submission.php 